\title{
Front Matter: Volume 9782
}

, "Front Matter: Volume 9782," Proc. SPIE 9782, Advanced Etch Technology for Nanopatterning V, 978201 (21 March 2016); doi: 10.1117/12.2239794

SPIE. Event: SPIE Advanced Lithography, 2016, San Jose, California, United States 


\title{
PROCEEDINGS OF SPIE
}

\section{Advanced Etch Technology for Nanopatterning $V$}

\author{
Qinghuang Lin \\ Sebastian U. Engelmann \\ Editors
}

22-23 February 2016

San Jose, California, United States

Sponsored by

SPIE

Cosponsored by

Lam Research Corporation (United States)

Published by

SPIE 
The papers in this volume were part of the technical conference cited on the cover and title page. Papers were selected and subject to review by the editors and conference program committee. Some conference presentations may not be available for publication. Additional papers and presentation recordings may be available online in the SPIE Digital Library at SPIEDigitallibrary.org.

The papers reflect the work and thoughts of the authors and are published herein as submitted. The publisher is not responsible for the validity of the information or for any outcomes resulting from reliance thereon.

Please use the following format to cite material from these proceedings:

Author(s), "Title of Paper," in Advanced Etch Technology for Nanopatterning $V$, edited by Qinghuang Lin, Sebastian U. Engelmann, Proceedings of SPIE Vol. 9782 (SPIE, Bellingham, WA, 2016) Six-digit Article CID Number.

ISSN: 0277-786X

ISSN: 1996-756X (electronic)

ISBN: 9781510600171

Published by

SPIE

P.O. Box 10, Bellingham, Washington 98227-0010 USA

Telephone +1 3606763290 (Pacific Time) · Fax +1 3606471445

SPIE.org

Copyright (C) 2016, Society of Photo-Optical Instrumentation Engineers.

Copying of material in this book for internal or personal use, or for the internal or personal use of specific clients, beyond the fair use provisions granted by the U.S. Copyright Law is authorized by SPIE subject to payment of copying fees. The Transactional Reporting Service base fee for this volume is $\$ 18.00$ per article (or portion thereof), which should be paid directly to the Copyright Clearance Center (CCC), 222 Rosewood Drive, Danvers, MA 01923. Payment may also be made electronically through CCC Online at copyright.com. Other copying for republication, resale, advertising or promotion, or any form of systematic or multiple reproduction of any material in this book is prohibited except with permission in writing from the publisher. The CCC fee code is 0277-786X/16/\$18.00.

Printed in the United States of America.

Publication of record for individual papers is online in the SPIE Digital Library.

\section{SPIE. DIGITAL}

Paper Numbering: Proceedings of SPIE follow an e-First publication model. A unique citation identifier (CID) number is assigned to each article at the time of publication. Utilization of CIDs allows articles to be fully citable as soon as they are published online, and connects the same identifier to all online and print versions of the publication. SPIE uses a six-digit CID article numbering system structured as follows:

- The first four digits correspond to the SPIE volume number.

- The last two digits indicate publication order within the volume using a Base 36 numbering system employing both numerals and letters. These two-number sets start with 00, 01, 02, 03, 04, $05,06,07,08,09,0 A, 0 B \ldots$ OZ, followed by 10-1Z, 20-2Z, etc. The CID Number appears on each page of the manuscript. 


\title{
Contents
}

\author{
$\checkmark \quad$ Authors \\ vii Conference Committee \\ ix Introduction
}

NANOPATTERNING FOR ADVANCED LOGIC AND MEMORY TECHNOLOGY NODES

978209 Patterning challenges in advanced device architectures: FinfETs to nanowires (Invited Paper) [9782-8]

9782 OB Plasma etch patterning of EUV lithography: balancing roughness and selectivity trade off [9782-10]

9782 0C Plasma etching processes for the integration of InP based compounds on 200mm Si wafer for photonic applications [9782-11]

PATTERNING INTEGRATION SCHEMES (MULTILAYER PATTERNING, SELF-ALIGNED PATTERNING, ETC.)

9782 OE Optical metrology for advanced process control: full module metrology solutions (Invited Paper) [9782-13]

9782 OG PMMA removal selectivity to PS using dry etch approach: sub-10nm patterning application [9782-15]

PATTERNING MATERIALS AND ETCH: JOINT SESSION WITH CONFERENCES 9779 AND 9782

$9782 \mathrm{OH}$ Evaluation of ALE processes for patterning (Invited Paper) [9782-16]

9782 ol Edge roughness characterization of advanced patterning processes using power spectral density analysis (PSD) (Invited Paper) [9782-17]

EMERGING PATTERNING TECHNOLOGIES (DSA, AND OTHER)

9782 0J Atomic precision etch using a low-electron temperature plasma (Invited Paper) [9782-18]

9782 OK Interactions between plasma and block copolymers used in directed self-assembly patterning (Invited Paper) [9782-19]

$97820 \mathrm{M} \quad 450 \mathrm{~mm}$ etch process development and process chamber evaluation using 193i DSA guided pattern [9782-21] 
INTERACTIVE POSTER SESSION

9782 ON Predicting LER and LWR in SAQP with 3D virtual fabrication [9782-22]

$978200 \quad$ Etch proximity correction through machine-learning-driven etch bias model [9782-23]

9782 OP Reactive ion etching challenges for half-pitch sub-10-nm line-and-space pattern fabrication using directed self-assembly lithography [9782-24]

$97820 Q \quad$ LER improvement for sub-32nm pitch self-aligned quadruple patterning (SAQP) at back end of line (BEOL) [9782-25] 


\section{Authors}

Numbers in the index correspond to the last two digits of the six-digit citation identifier (CID) article numbering system used in Proceedings of SPIE. The first four digits reflect the volume number. Base 36 numbering is employed for the last two digits and indicates the order of articles within the volume. Numbers start with 00, 01, 02, 03, 04, 05, 06, 07, 08, 09, OA, OB...0Z, followed by 10-1Z, 20-2Z, etc.

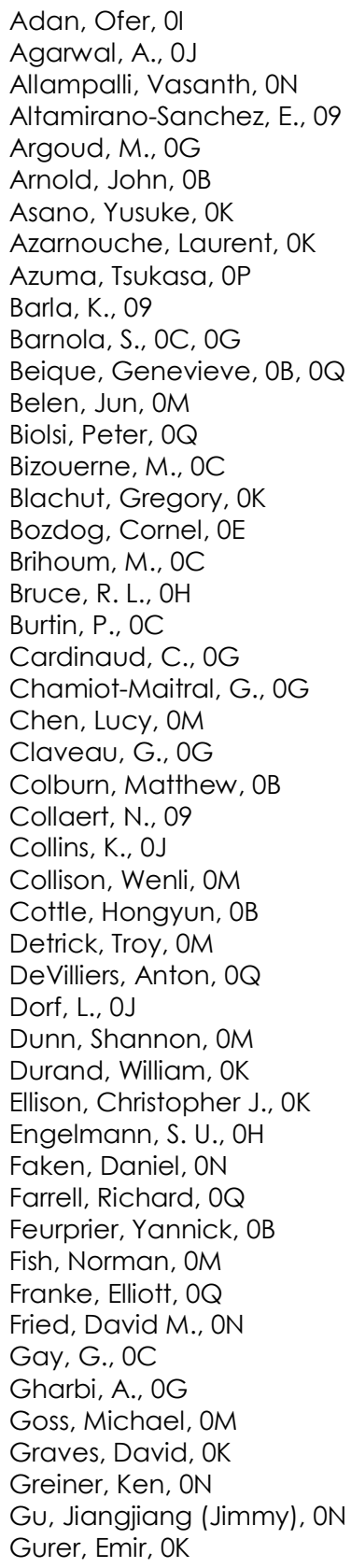

\author{
Horiguchi, N., 09 \\ Hosler, Erik, $O Q$ \\ Hubert, H., 09 \\ Hymes, Diane, OK \\ Janes, Dustin, OK \\ Joseph, E. A., $\mathrm{OH}$ \\ Kanai, Hideki, OP \\ Kasahara, Yusuke, OP \\ Kawamonzen, Yoshiaki, OP \\ Kelling, Mark, OM \\ Kenney, J., OJ \\ Kihara, Naoko, OP \\ Kikuchi, Y., 09 \\ Kim, M. S., 09 \\ Kim, Ryoung-Han, $0 Q$ \\ Ko, Akiteru, OQ \\ Kobayashi, Katsutoshi, OP \\ Kodera, Katsuyoshi, OP \\ Kris, Roman, $\mathrm{Ol}$ \\ Kubota, Hitoshi, OP \\ Kumar, Kaushik, OB \\ Labelle, Cathy, $O B, O Q$ \\ Levi, Shimon, Ol \\ Lin, Pinyen, OM \\ Lin, Yii-Cheng, OM \\ Maher, Michael, OK \\ Marchack, N., OH \\ Mertens, H., 09 \\ Metz, Andrew, OB \\ Milenin, A. P., 09 \\ Minegishi, Shinya, OP \\ Miyagi, Ken, OP \\ Miyazoe, $\mathrm{H}$., $\mathrm{OH}$ \\ Mohanty, Nihar, $\mathrm{OQ}$ \\ Mori, Kazunori, OK \\ Navarro, C., OG \\ Nicolet, C., OG \\ Papalia, J. M., $\mathrm{OH}$ \\ Pargon, E., OC \\ Paris, James, OM \\ Park, Minjoon, $O M$ \\ Periera, Cheryl, $0 Q$ \\ Petit-Etienne, C., OC \\ Pimenta Barros, P., OG \\ Piumi, D., 09 \\ Posseme, N., OG \\ Raghavan, P., 09 \\ Ragnarsson, L.- $\AA_{\text {., }} 09$ \\ Ramaswamy, K., OJ
}


Ranjan, Alok, OB

Rastogi, Vinayak, OB

Rauf, S., OJ

Sarrazin, A., OG

Sato, Hironobu, OP

Schwarzband, Ishai, ol

Seino, Yuriko, OP

Shi, Elly, Ol

Shim, Seongbo, 00

Shin, Youngsoo, 00

Shiraishi, Masayuki, OP

Sirard, Stephen, OK

Smith, Jeffrey, $O Q$

Someya, Yasunobu, OK

Stojakovic, George, OM

Subhadeep, Kal, OQ

Sun, Chih-Ming, $O M$

Sun, Lei, OB, OQ

Takikawa, Hiroaki, OM

Tao, Z., 09

Thean, A. V.-Y., 09

Tiron, R., OG

Tobana, Toshikatsu, OP

Turovets, Igor, OE

Veloso, A., 09

Verdujn, Erik, $O Q$

Waldron, N., 09

Wang, J.-C., OJ

Wang, Wenhui, $0 Q$

Willson, C. Grant, OK

Witters, L., 09

Yamano, Hitoshi, OP

Zhang, Ying, Ol, OJ

Zhao, Dalong, ON

Zhou, Kevin, Ol 


\section{Conference Committee}

Symposium Chair

Mircea V. Dusa, ASML US, Inc. (United States)

Symposium Co-chair

Bruce W. Smith, Rochester Institute of Technology (United States)

Conference Chair

Qinghuang Lin, IBM Thomas J. Watson Research Center

(United States)

Conference Co-chair

Sebastian U. Engelmann, IBM Thomas J. Watson Research Center (United States)

Conference Program Committee

Efrain Altamirano-Sánchez, IMEC (Belgium)

Julie Bannister, Tokyo Electron America, Inc. (United States)

Sang-Hoon Cho, SK Hynix, Inc. (Korea, Republic of)

Maxime Darnon, LTM CNRS (France)

Eric A. Hudson, Lam Research Corporation (United States)

Catherine B. Labelle, GLOBALFOUNDRIES Inc. (United States)

Nae-Eung Lee, Sungkyunkwan University (Korea, Republic of)

Gottlieb S. Oehrlein, University of Maryland, College Park (United States)

Erwine Pargon, LTM CNRS(France)

Nicolas Posseme, CEA-LETI (France)

Ricardo Ruiz, HGST, Inc. (United States)

Seiji Samukawa, Tohoku University (Japan)

Robert Turkot, Intel Corporation (United States)

Rich Wise, Lam Research Corporation (United States)

Jeff Xu, Qualcomm Technologies Inc. (United States)

Anthony Yen, TSMC Taiwan (Taiwan) 
1 Overviews of Nanopatterning Challenges

Catherine Labelle, GLOBALFOUNDRIES Inc. (United States)

Robert Turkot, Intel Corporation (United States)

Richard J. Wise, Lam Research Corporation (United States)

2 New Plasma Sources and New Etching Technologies

Seiji Samukawa, Tohoku University (Japan)

Nicolas Posseme, CEA-LETI (France)

Julie Bannister, Tokyo Electron America, Inc. (United States)

3 Nanopatterning for Advanced Logic and Memory Technology Nodes

Sang-Hoon Cho, SK Hynix, Inc. (Korea, Republic of)

Eric A. Hudson, Lam Research Corporation (United States)

4 Patterning Integration Schemes (multilayer patterning, self-aligned patterning, etc.)

Maxime Darnon, LTM CNRS (France)

Nae-Eung Lee, Sungkyunkwan University (Korea, Republic of)

Efrain Altamirano-Sánchez, IMEC (Belgium)

5 Patterning Materials and Etch: Joint Session with Conferences 9779 and 9782

Douglas Guerrero, Brewer Science, Inc. (United States)

Qinghuang Lin, IBM Thomas J. Watson Research Center

(United States)

6 Emerging Patterning Technologies (DSA, and other)

Ying Zhang, Applied Materials, Inc. (United States)

Ricardo Ruiz, HGST, Inc. (United States) 


\section{Introduction}

This proceedings volume contains accepted papers from the SPIE conference on Advanced Etch Technology for Nano-patterning $V$ (The SPIE Etch conference) held as part of the International Symposium on Advanced Lithography, 21-25 February 2016, in San Jose, California, United States. These proceedings papers cover the latest advances in the wide field of etch and nano-patterning technology and offer a glimpse of the state-of-the-art of this important field of semiconductor technology.

This year's SPIE Etch conference continued the fine tradition of having a wide international representation and attracted many researchers from related fields. As in previous years, our conference lasted two days, with the papers divided into six sessions (listed below) which continued to garner tremendous interests among conference attendees.

- Overviews of Nano-Patterning Challenges

- New Plasma Sources and New Ełching Technologies

- Nano-Patterning for Advanced Logic and Memory Technology Nodes

- Patterning Integration Schemes (multilayer patterning, self-aligned patterning, etc.)

- Patterning Materials and Etch: Joint Session with conference 9779

- Emerging Patterning Technologies (DSA, and others)

This year, the Etch conference hosted a well-attended joint session on Patterning Materials and Etch with the Advances in Patterning Materials and Processes conference 9779. The overview session of the Etch conference drew very big crowds, where some of the most important fundamental issues faced in the world of nano-patterning and etch were discussed.

We hope that this proceedings volume proves valuable to the many patterning scientists and engineers working in the fast-moving semiconductor industry. We also hope that it serves as a useful reference for those who are interested in nanofabrication, micro- and nano-fluidics, micro- and nano-photonics, MicroElectro-Mechanical Systems (MEMS), BioMEMS, organic electronics, advanced packaging, and bio-chips.

We thank the authors, particularly the invited speakers, for their valuable contributions to the conference and proceedings volume. The SPIE Etch conference is highly regarded among the worldwide patterning community simply because of the high quality of our talks and proceedings papers. 
We also thank members of the organizing committee for their dedication and hard work to help maintain a high quality of this conference. We are also grateful to LAM Research Corporation (United States) for their generous financial support. Finally, we extend our sincere thanks to the SPIE staff for their tireless efforts and their meticulous organizational skills in helping make this year's SPIE Etch conference a success and in assembling and publishing this proceedings volume.

\section{Qinghuang lin Sebastian U. Engelmann}

